\title{
A geographical and architectural perspective on Alpine hay meadow abandonment in Bohinj, Slovenia
}

\author{
Domen Kušar \& Blaž Komac
}

Keywords: geography, architecture, land abandonment, hay meadows, wooden hay barn, cultural heritage, Uskovnica Pasture, Slovenia

\section{Abstract}

This paper presents a combination of architectural and geographical methods for studying the abandonment of Alpine cultural landscapes. It examines the afforestation of hay meadows above the Uskovnica Pasture in the Bohinj Mountains in Slovenia's Julian Alps. Written sources on the intensity of changes are rare for mountainous areas, and so auxiliary means can be used as indicators. These include abandoned architectural elements, such as the hay barns discussed here. This paper presents a classification of the levels of decay of these buildings, which were used to store fodder over the winter. It uses them as an innovative indicator of changes in the cultural landscape. The study presents the results of a comprehensive, long-term examination of a disappearing cultural heritage: hay meadows in a sensitive protected mountain area of the Alps.
Profile

Protected area

\section{Triglav NP}

Mountain range

Alps

Country

\section{Slovenia}

\section{Introduction}

The Alps are characterized by landscape (Perko et al. 2017), economic (Tasser et al. 2007) and regional diversity (Gabrovec et al. 2017). In some areas, low economic development and out-migration prevail (Nared et al. 2015; Hinojosa et al. 2016) and lead to land abandonment. This paper examines the abandonment of an Alpine cultural landscape - the mountain meadows above the Uskovnica Pasture, Slovenia, located in the southwest of the Pokljuka Plateau (1100 m a.s.l.) in eastern Slovenia's Julian Alps (Figure 1). The area belongs to Conservation Area 3 of the Triglav National Park (TNP). The National Park is divided into three conservation areas of different levels of protection: the first (37.5\% of the territory), second (38.6\%) and third $(23.9 \%)$ conservation areas, the first being the most restrictive as regards human influence. The third conservation area is intended to preserve and protect biodiversity and the cultural landscape by promoting sustainable development of settlements (Zakon o Triglavskem narodnem parku 2010, Article 6). The area was used as a temporary pasture for the livestock which was taken there in the first half of May. In July, the animals were driven to higher altitudes, and the area was mown for hay, which was dried for winter in the hay barns (Melik 1950; Cevc 1992). This was necessary due to the geographical conditions in the Bohinj Valley, which is characterized by small parcels on rugged terrain (Melik 1950), high precipitation (2900 $\mathrm{mm}$ over 150 precipitation days) and long-lasting snow cover (Ogrin 1996).

Hay meadows traditionally provided opportunities for economic activity and integrated people in the mountain environment (see Scotton et al. 2014), but since mowing stopped in the second half of the twentieth century, the hay meadow cultural landscape is now nearing extinction. Modernization of farming in the Alps has led to depopulation and land-use abandonment in both remote areas (MacDonald et al. 2000; Plieninger et al. 2006; Fuchs et al. 2015; Terres et al. 2015; Lasanta et al. 2016), and in others which are less favorable for farming (Ciglič et al. 2012). Bohinj belongs to the Alpine regions where the population growth was high between 1871 and 1951, and its population was stable from 1981 to 2000 (Bätzing \& Dickhörner 2001; Bole et al. 2016; Bender et al. 2017), but people were forced to abandon their traditional ways of farming to go and work in the valley. This process was accelerated by industrialization after the Second World War. Unlike other parts of the Alps, former Yugoslavia supported industrialization as a source of progress and inhibited the development of tourism and other tertiary activities (Bätzing 1988).

In the Slovenian Alps, natural afforestation took place, and the share of forest increased from $45 \%$ in 1827 to over $70 \%$ in 2000 (Gabrovec \& Kladnik 1997). In the study area, too, afforestation is currently the most important process.

The traditional barns used for centuries to store hay over the winter are now decaying, thus reflecting the processes of land abandonment and afforestation (Andrič et al. 2010). We argue that although this cultural landscape originates in the past, it is still relevant for the future (Komac 2009; Scotton et al. 2014) as it hosts important cultural heritage, in the form of the wooden hay barns. Agricultural landscapes in fragile Alpine environments are important not simply for their beauty: they also promote cultural ecosystem services, such as spiritual, aesthetic and cultural heritage values, recreation and ecotourism, as well as biodiversity conservation (Assandri et al 2018). The hay barns were used 




Figure 1 - Research area above the Uskovnica Pasture.

in this study, in addition to plant succession, as an indicator of traditional land use abandonment. Even though similar buildings can be found elsewhere, the hay barns are an indelible part of the hay meadow cultural landscape and reflect the former traditional use of mountainous areas (Juvanec 2009; Juvanec \& Zupančič 2014). But for the historical and economic reasons mentioned above (depopulation of the higher grounds in favour of work in other sectors), it is impossible to preserve them in a financially viable manner.

These buildings reflect the natural environment in which they are located, and so log cabins made using the solid timber wall method predominate over stone and timber frame buildings (Table 2). Timber wall buildings are made of spruce logs following a construction method that is widespread in the Alps and which goes back to at least the Hallstatt period (1200-1000 BC) (Kušar 2008). The buildings rest on four corner stones. The larger ones have ceilings constructed with beams; the smaller ones only have rafters attached to the timbers around the sides. They were used as hay barns and for human habitation. Hay barns do not have doors or other openings in the walls because the hay was piled up inside and taken out through a triangular opening under the roof in one of the gable ends. Because the hay had to be kept dry, the floor is usually raised from the ground, made of planks or poles resting on beams. Residential buildings have openings in the walls that are reinforced with dowels. In the study area, wooden residential buildings and stone buildings with wooden roof beams were not very common, because this was not a grazing pasture in the proper sense of the word (Cevc 1995). Only two buildings in the area were made following the timber frame method. Except for five renovated buildings, all the other buildings, including the ruined ones, were roofed with wooden shingles.

\section{Methods}

This paper uses architectural and geographical methods to present hay barns as a possible indicator of landscape changes in the Alps. It also presents the afforestation of agricultural areas in the protected part of the Slovenian Alps, and its impacts on architectural heritage. A database of buildings was created which can be used as a model for managing other fragile mountain cultural landscapes. Based on the analysis of the afforestation of hay meadows and documenting the hay barns in the area above the Uskovnica Pasture, the paper presents a model of changes in the Alpine cultural landscape and the relevant factors of influence. The conclusions can be used in future research or as an expert basis for decision-makers.

Current conditions in the study area, which consists of parcels with hay meadows above the Uskovnica Pasture and covers 73.5 ha, were determined. The buildings were located using historical cadasters from 1826 (ARS 2016), current cadasters (GURS 2015), aerial photographs (GIS 2015), satellite images from various dates, and Lidar data (ARSO 2015). The GERK online parcel application (MKGP 2015), aerial photographs and GPS (Garmin Etrex Vista) were used for field studies. The figures were produced using $A u$ toCAD 2013 software.

The share of forest in 1826 was determined from the Land Cadastre (ARS 2016), in which land use was described for individual parcels. The parcel land-use data were then used to calculate the forest area. For the years 1956, 1980 and 2016, forest area (percentage) was determined by analysing the aerial and orthophotographic images of the years in question obtained by the Surveying and Mapping Authority of the Republic of Slovenia and using the AutoCAD program. This program was also used to create Figure 4, which shows areas covered by forest in 1826, 1956, 1980 and 


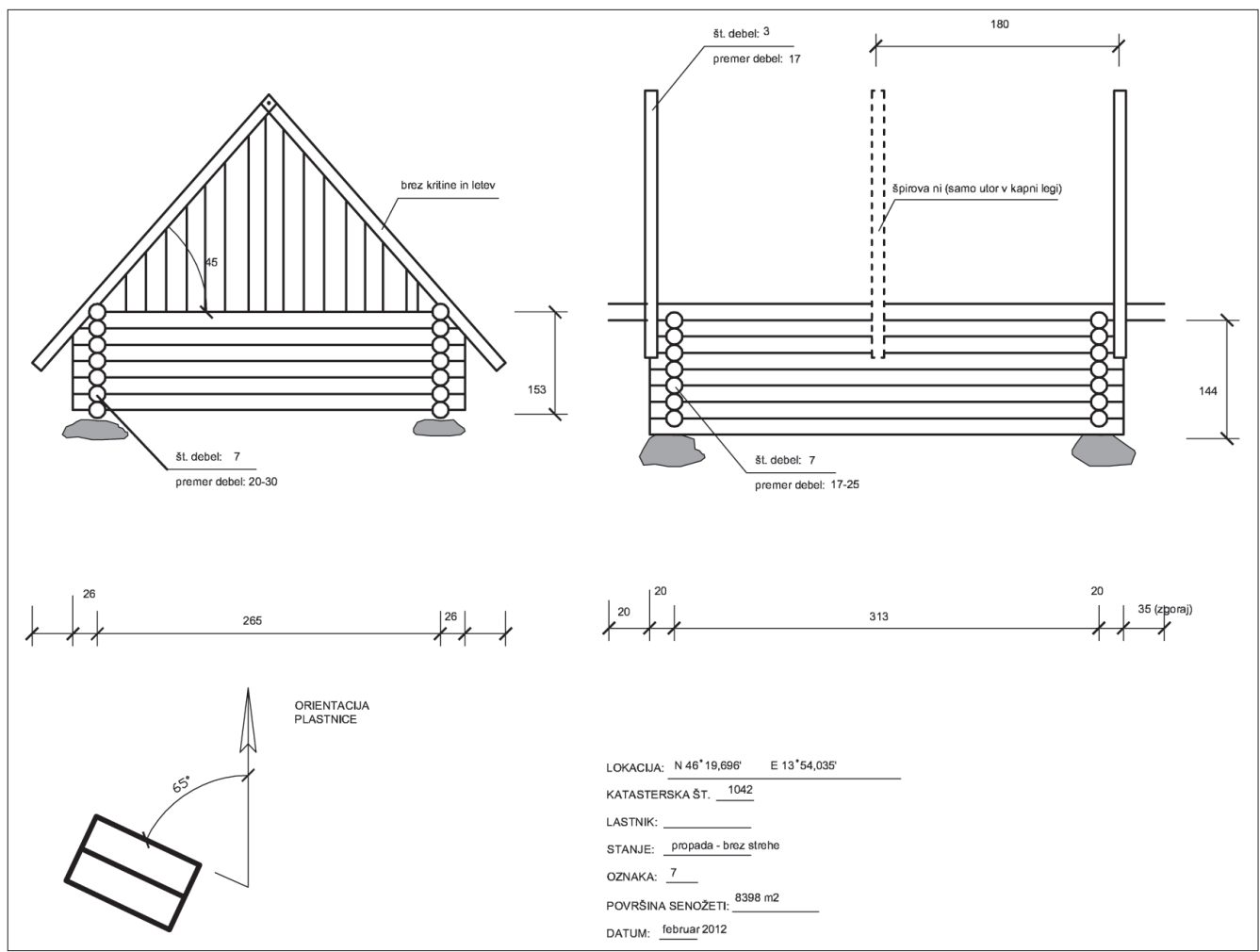

Figure 2 - Example of a document from the archive (Kǔsar \& Kǔar 2018) for a hay barn, presenting location, cadastre number, owners' names, state, area and date. (C) Kušar

2016. Figure 4 was produced using the cadastral map or aerial photo layer, the parcel boundaries, and the boundaries of the research area layer. The extent of the forest, individual trees and groups of trees were then determined, and the final layer, representing the changing forest area, was produced. We were then able to determine the share of forests in the area under consideration for the period 1826 to 2016 using the AutoCAD 2013 program.

Readers should note, however, that in Slovenia the Surveying and Mapping Authority records actual and planned land use (forest land, agricultural land...) for each parcel, and that the share (percentage) of planned and actual land uses can vary greatly depending on the frequency with which the database is updated. Likewise, both values can differ from the situation in nature. Our continuous multi-annual fieldwork has shown that the forest area reached its greatest extent in the period 2010 to 2015 , since some parts of the forest have been cut down since 2015 .

An archive was produced documenting each building identified (Figure 2), using the documentation form created by the authors and inspired by the method used by Fister (2002) for the Corpus of Slovenian Architecture (ARS 2016). Additional information was obtained using the e-Land Register portal (VSRS 2015) and data provided by the Surveying and Mapping Authority of the Republic of Slovenia (GURS 2015).

A building's degree of preservation was determined by analysing the state of individual building elements and the possibility (or not) of renovating or replacing the damaged parts. Six levels were established (Figure 3). The levels were developed by the authors according to the sequence for the deterioration of the vital elements of wooden buildings due to moisture, and by taking into account whether the elements of a wooden building could be renovated, as presented by Herzog et al. (2008) and in a paper on wood decay (United States Department of Agriculture, Forest Service 1986). The classification for deterioration is therefore transferable to other areas with a similar geographical context.

Level A includes buildings without visible damage. Level B includes buildings with deteriorating roofs, in which the roof beams are not damaged to the point where they need to be replaced, and so only the roofing needs to be replaced. Level-C buildings have ruined roofing or badly damaged rafters, so both the beams and the roofing need to be replaced, but not the wall construction. For level D, the roof has completely collapsed and the upper logs forming the walls have also been damaged, necessitating their replacement. For level E, the walls are so badly damaged that renovation is no longer possible, although the extent of the building's layout can still be identified. A ruined building (level F) means that it is still possible to find the decaying remains of logs and nails, and perhaps some of the building's contents, such as farm tools. For this category, it is usually possible to determine the building's precise location extent and purpose.

For the hay barns in our study area, the decay rate was calculated based on the data for the succession 

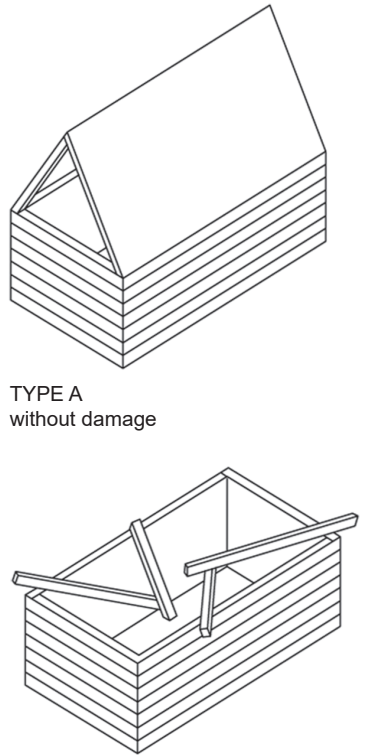

TYPE D collapsed roof
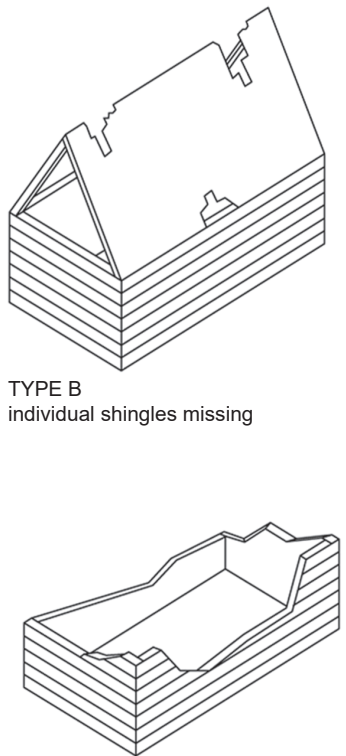

TYPE E

damaged side timbers

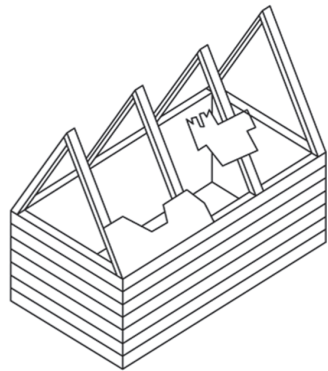

TYPE C

ruined shingles, damage rafters

Figure 3 - Sequence of the deterioration of a hay barn. (C) Kǔar

from one level of deterioration to the next (A-E). The speed of deterioration from one level to the next was calculated for each building and then averaged. The data were then used to provide an average decay rate. This enables us to predict roughly what the situation will be in the future, which is important for governance of land use and other activities in the TNP protected area, but also in other similar geographical contexts.

\section{Results}

\section{Deforestation and afforestation}

In the Slovenian Alps, first the grassland areas above the tree line were used for grazing (Cevc 1992); later on, people started cutting down forests. The forest in the study area was cleared before the first cadasters were produced: in 1826, 97\% of the area comprised pastures and meadows (Figure 4).

Even as late as 1956 and 1980, there were only a few trees in the hay meadows studied. This was followed by a period during which mowing was abandoned and afforestation took place. In the past five years, not even a single hay barn was used for storing
Table 1 - Land use in the hay meadows studied (GURS 2015).

\begin{tabular}{|l|r|r|}
\hline \multirow{2}{*}{ Land use } & Planned use & Actual use \\
\cline { 2 - 3 } & \multicolumn{2}{|c|}{$[\%]$} \\
\hline Prime and other agricultural land & 86.0 & 13.7 \\
\hline Forest & 14.0 & 85.9 \\
\hline Built-up area & 0.0 & 0.4 \\
\hline
\end{tabular}

hay. The percentage of forest was the highest between 2005 and 2010 (95\%), while in spring 2016 the area was $6.77 \%$ meadows and pastures and $93.22 \%$ forest (Figure 4).

In terms of planned land use, most of the area is categorized as prime or other agricultural land. However, the situation is exactly the opposite with regard to actual use, with forest being the predominant element (Table 1). The great discrepancy between planned and actual use points to the intensity of afforestation, which was also confirmed by the analysis of aerial photographs (GIS 2015). The oldest aerial photograph available (from 1956) shows that individual trees grew fairly evenly across the hay meadows.

Table 2 - Condition of 60 buildings, their intended use and construction type.

\begin{tabular}{|l|r|r|r|r|}
\hline Condition & $\begin{array}{l}\text { Standing } \\
\text { (Level A) }\end{array}$ & $\begin{array}{l}\text { Deteriorating } \\
\text { (Levels B-E) }\end{array}$ & $\begin{array}{l}\text { Only the location can } \\
\text { be identified (Level F) }\end{array}$ & $\begin{array}{l}\text { Gone } \\
\text { completely }\end{array}$ \\
\hline Use & & & & 10 \\
\hline Hay barn & 5 & 8 & 0 & 0 \\
\hline $\begin{array}{l}\text { Other buildings (e. g. residential, other farming } \\
\text { or auxiliary buildings) or not possible to identify }\end{array}$ & 29 & 0 & & \\
\hline Construction & & 22 & & 10 \\
\hline Solid timber & 1 & 8 & 0 & 0 \\
\hline Timber frame & 11 & 0 & 0 & 0 \\
\hline Stone \& timber & 0 & 0 & 0 & 0 \\
\hline Not possible to identify & & 0 & 0 \\
\hline
\end{tabular}




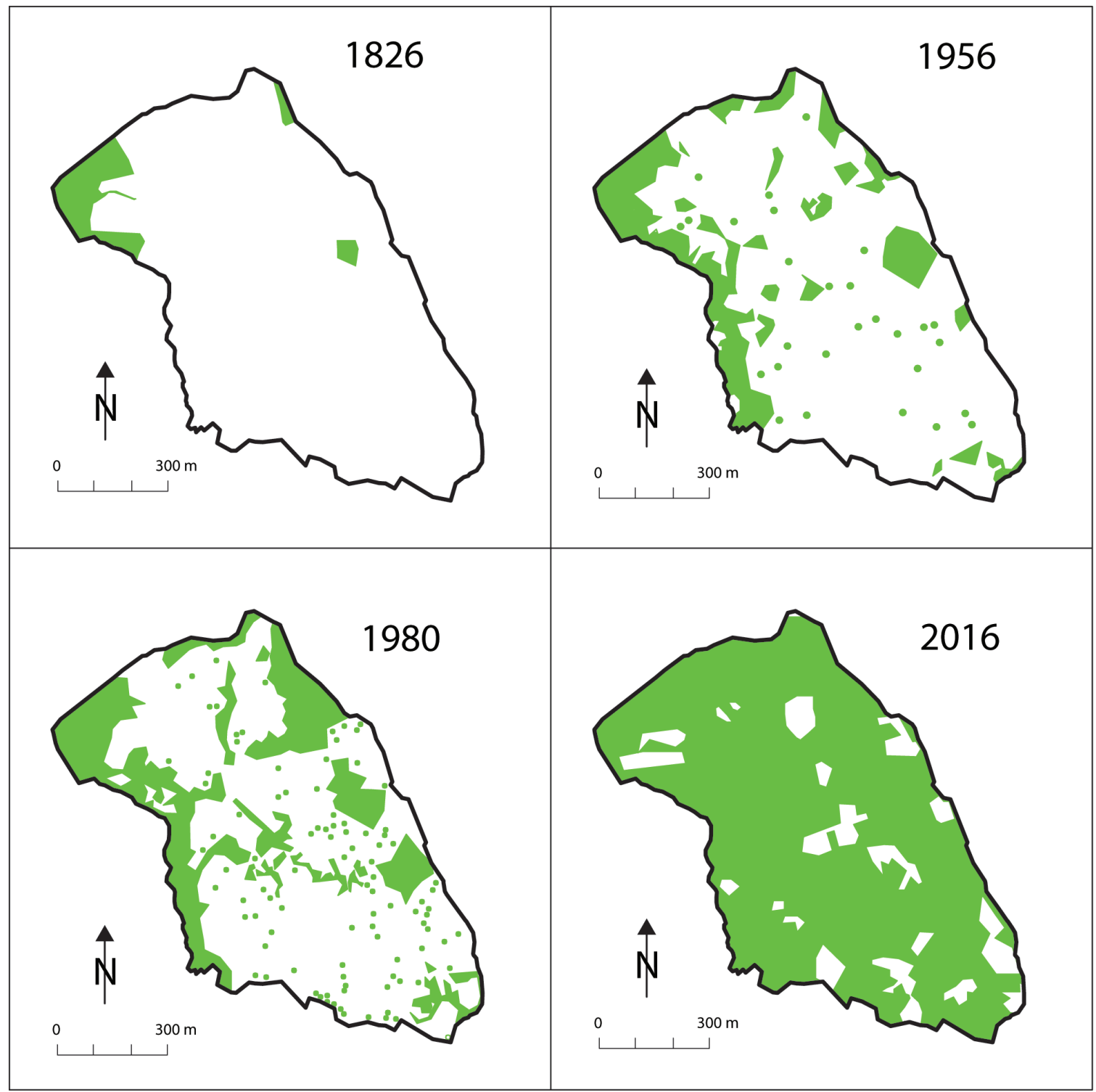

Figure 4 - Tree-covered area (green) in 1826 (based on cadastral data), 1956, 1980 and 2016 (based on aerial photos) (ARS 2016; GURS 2015).

Common beech (Fagus sylvatica) usually grew next to hay barns. This considerably accelerated the later afforestation, as the seeds were distributed dozens of metres away from the parent tree, with one-third of the trees being seeded within four to five years after abandonment and one-third within six to fifteen years. The process then slowed down significantly, and after fifteen years forest predominated in some areas at elevations of 800 to $1200 \mathrm{~m}$ (Tasser et al. 2007).

A comparison of the 1826 cadastre (Figure 5) and the present situation shows small differences. There was little parcel sharing or pooling. Some individual breakdowns of boundaries occurred due to the sale of a building (and the land around it) to a new owner. Abandonment and afforestation also demonstrate that the state of their land is relatively unimportant to owners. On the other hand, the attachment of the population to the land, the legislation that makes agricultural land sales to non-farmers more difficult, and the prohibition of the construction of buildings and changes in use within the TNP have caused cadaster plots to remain as they were.

\section{Buildings}

Originally $71 \%$ of all parcels had a building on them (Figures 5, 6, and 7). In 1826, there were 47 buildings in the study area; today the cadaster shows 53 sites with buildings, which our study found to be in various states of preservation. The cadaster also includes buildings that have completely vanished. The records of the Slovenian Surveying and Mapping Authority (GURS, 2015) include 9 residential and 23 non-residential buildings; as many as 30 hay barns are not listed at all. The majority of buildings correspond to their original locations, recorded when the cadaster was first produced. Based on the field inspection, we found buildings in various states of preservation ( $\mathrm{Ta}-$ ble 2 and Figure 7). 


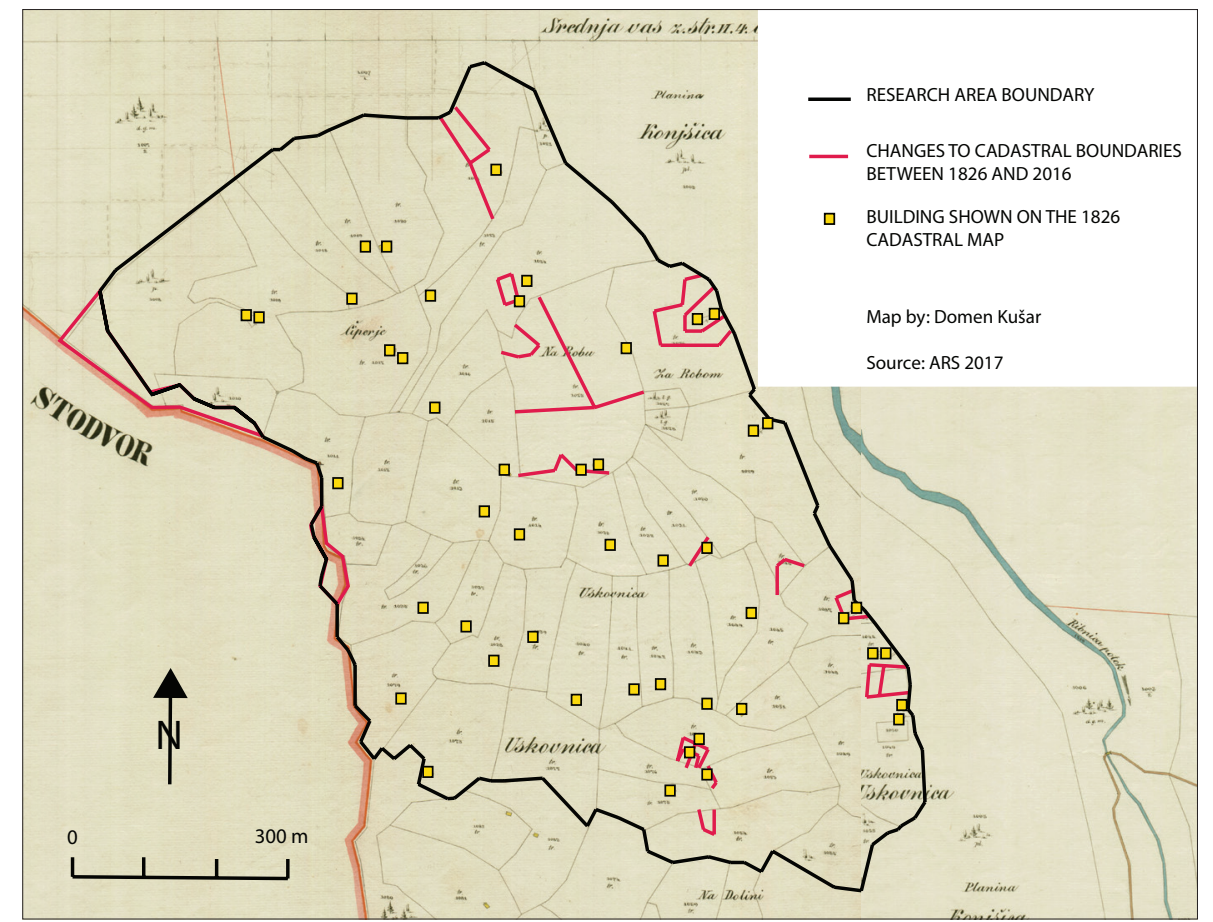

Figure 5-Changes to cadastral borders from 1826 to 2016.

The majority of the buildings were originally used as hay barns. Later on, the number of outbuildings decreased and the number of residential buildings increased. In the past 200 years, 23 hay barns have kept their intended use. Of these, 16 are falling into ruins, and for two of them the location and purpose can be identified only from their remains. There are 17 residential buildings in the area, mostly holiday homes built from scratch or converted from older outbuildings in the 1980s, before the TNP extended into this area. Half of the buildings and $70.3 \%$ of the parcels are owned or at least co-owned by locals (Table 3).

The deterioration of the buildings depends primarily on the intensity of the afforestation in their direct vicinity. It is difficult to determine the exact chronological course of this deterioration because it is influenced by many factors, such as humidity (Torelli \& Čufar 1983), light (Hon 1991), fungi and insects (Pohleven 1998), and micro-location. If the roof is maintained, the deterioration process is slowed down, regardless of whether the building stands in a forest or an open space.

Of the 23 hay barns, only five are in a good condition (Figure 7). This is mostly thanks to the care of the owners, seen in roof renovation (four cases, or 17\%). Another measure is the maintenance of the environ- ment - preventing afforestation (three cases, or $13 \%$ ). Ten hay barns (44\%) are in a state of total ruin (level F), and $8(35 \%)$ are in various stages of decay. The process of decay is fast, which is shown in Figure 9 for the ten most-exposed barns. On average, a building will fall into the next level of decay in approximately five years if it is not renovated. Based on the procedure described in the methods section, it can be deduced that the average linear decay rate for the period 2016-2035 will be about 0.5 units per year, which equates to an annual decline of about $4.8 \%$. The decay rate is exponential and can be described by the following equation:

$$
y=1.038 e^{-0,073 x}\left(R^{2}=0.93\right) .
$$

If they are not maintained, the current (for year 2016) 10 buildings will fall to an estimated 9 in 2020, 5 in 2025, 4 in 2030, and just 3 in 2035. In just 20 years or so, if the most-exposed hay barns are not maintained all traces of the majority of them will probably disappear entirely from the surface of the ground.

The photographs taken over a longer period (Figure 8) show that a wooden building deteriorates to a point beyond repair in approximately thirty years (see green line in Figure 9), for which the only solution is to

Table 3 - Buildings by use in 1826 and in 2016.

\begin{tabular}{|l|r|r|r|}
\hline Type of building & $\mathbf{1 8 2 6}$ cadaster & $\mathbf{2 0 1 6}$ field inspection & Owned by locals \\
\hline Outbuilding (hay barn) & 32 & 23 & 18 \\
\hline Other outbuilding & 5 & 29 & 10 \\
\hline Not possible to identify & 10 & 8 & 6 \\
\hline Total & 47 & 60 & 31 \\
\hline
\end{tabular}




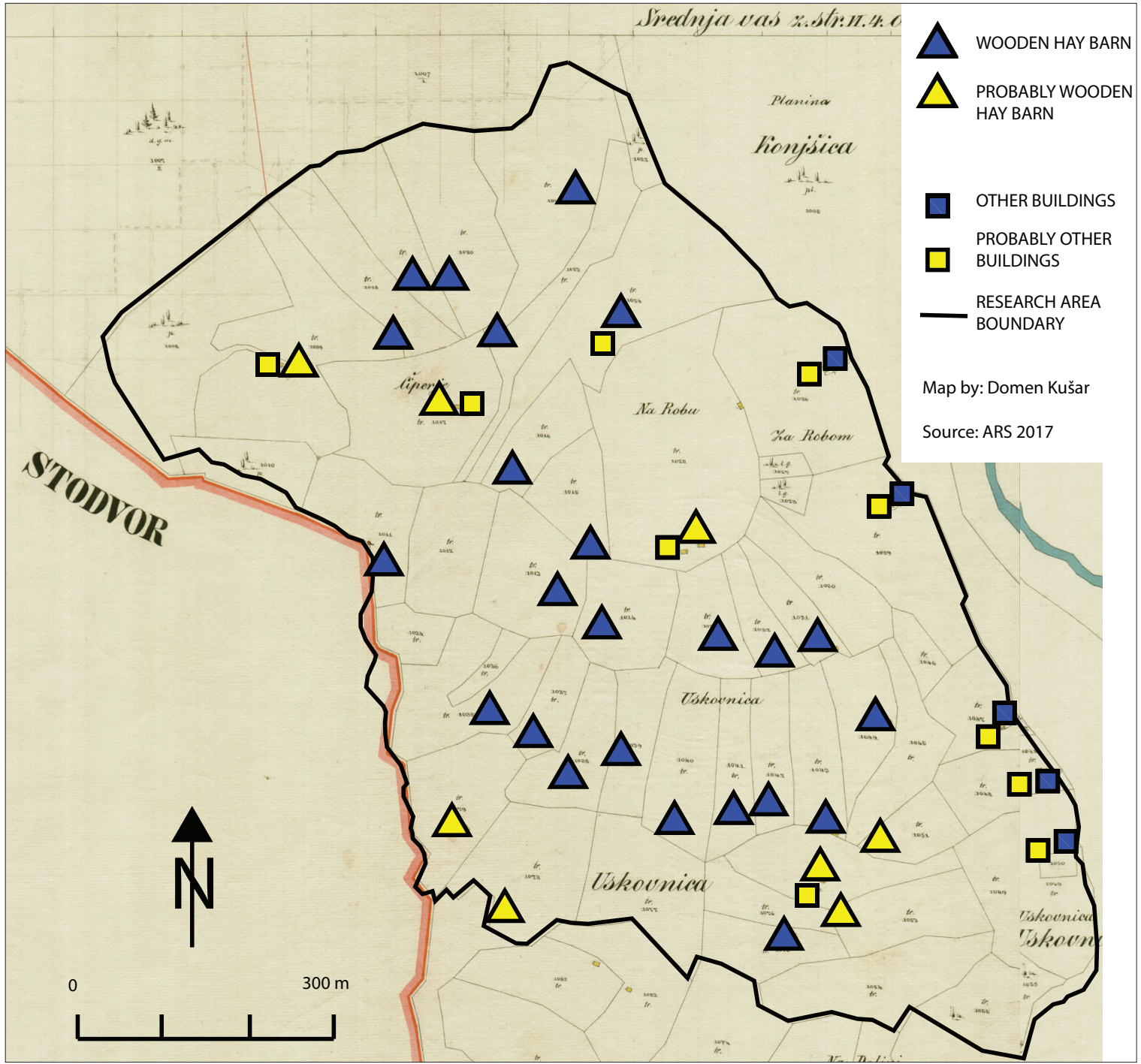

Figure 6 - Types of buildings around 1826.

replace it with a new building. In the study area, 78.3\% of hay barns are in various stages of decay or have already decayed completely. The buildings in the eastern part of the Uskovnica Pasture have avoided this process, thanks to repairs carried out to their roofs. Buildings made of a combination of stone and timber are less likely to be affected by the process of deterioration.

\section{Discussion}

Alpine landscapes contain a significant share of past landscape elements, including architectural ones such as hay barns. Inventorying these structures in part of the TNP over recent decades made it possible to archive data on individual structures and to relate them to the landscape processes that reflect socioeconomic development.

The area studied has a long history as a rural system maintained by people. In this case, one cannot talk about a natural condition of the landscape as a referential condition of protection regimes (Antrop
2005). The landscape does not simply revert to the original, pre-agricultural or natural landscape through land abandonment and afforestation, but becomes a new non-agricultural rural cultural landscape. Due to the absence of productive use, the emerging landscape is no longer people-friendly (Höchtl et al. 2005); moreover, its abandonment even has detrimental effects on environmental parameters (MacDonald et al. 2000), aesthetic value (Smrekar 2016), and economic activities such as tourism, as forest now predominates in the areas of the former hay meadows.

In this study the hay barns were used as a tool to qualitatively determine the intensity of the processes related to rapid afforestation and deterioration of the buildings due to lack of roof maintenance. Even though in principle the buildings that still exist are protected by the TNP Act (Zakon o TNP 2010), they have not been recognized and protected as part of the area's cultural heritage (Drole et al. 2012).

The deterioration of the hay barns resulted primarily from the social, cultural, economic and historical changes after the Second World War (i.e., during the 


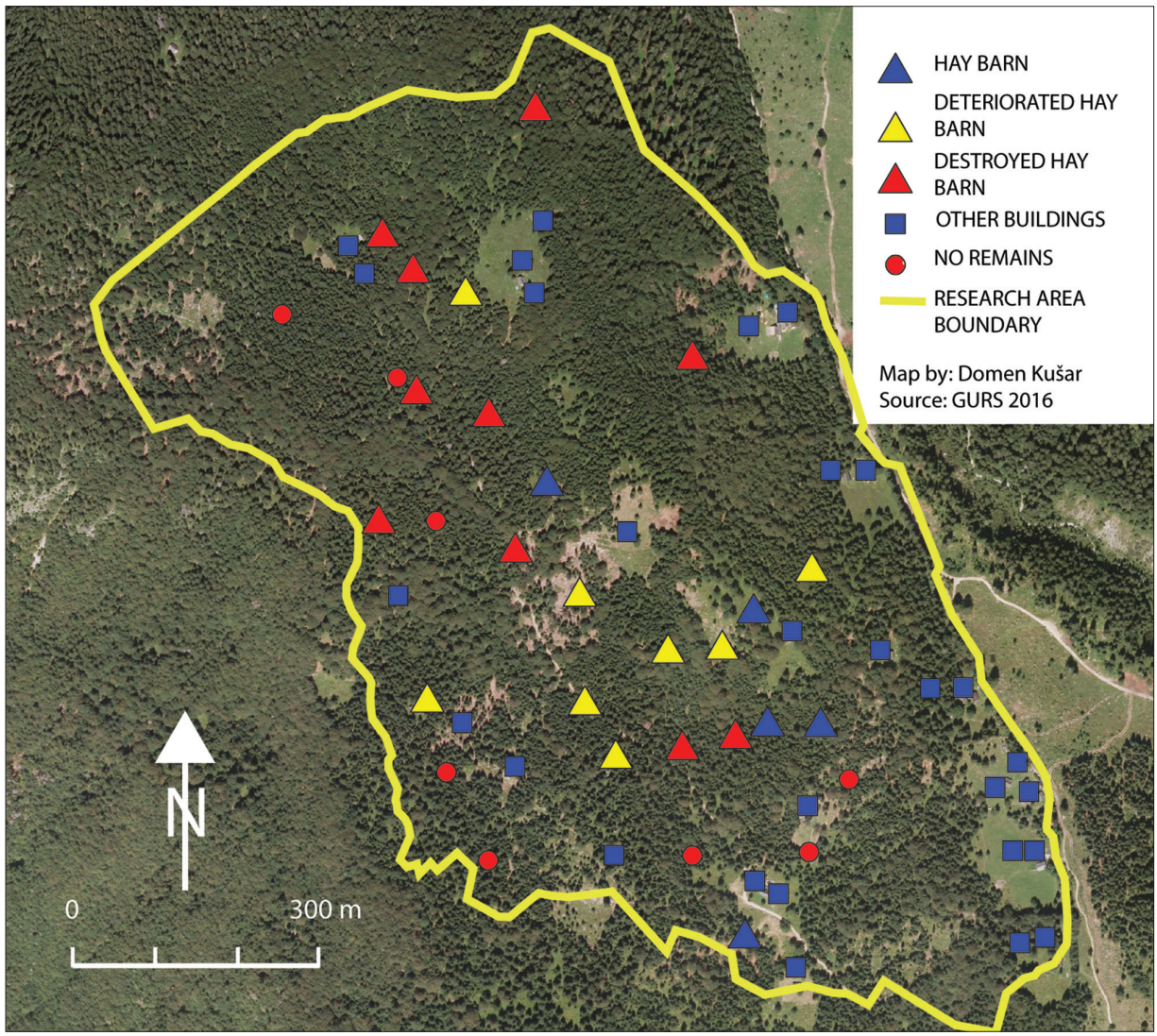

Figure 7 - Types and condition of buildings in 2016.

1950s and 1960s) in the Slovenian farming system (Pučnik 1965; Andrič et al. 2010), when a tenth of the buildings located primarily on the edges of the cadastral district or further away from the road began to deteriorate. As elsewhere in the Alps (Monteiro et al. 2011), the economic situation and the collapse of the communist system during the 1990s, and the subsequent globalization during the same decade, caused the deterioration of at least a quarter of the buildings in the area. Using the method proposed here, which relates architectural and geographical perspectives, we can assess future changes to the interesting Alpine cultural landscape of hay meadows, which are especially important in touristic protected areas, such as TNP.

In recent years, discussions have been held in the Bohinj area regarding the impact of TNP on local people's lives. The initial hopes for a positive attitude from the government and TNP later grew into disappointment over the restrictions imposed by the park, especially with regard to spatial changes (Gabrovec et al. 2017). The private owners of holiday homes who maintain the buildings and their surroundings also face problems, as they are often not allowed to reconstruct their buildings due to park restrictions (Koderman 2014).

The area studied is clearly at a tipping point. On the one hand, it contains cultural heritage elements linked to traditional Alpine farming that have been overlooked until now; on the other, it is subject to the strict requirements of the protected area of TNP.
Field research has shown that the grasslands around the residential buildings are maintained, but there is a rather large number of buildings at different stages of decay which, without maintenance, will disappear in the next few decades. As changes in the plant composition of hay meadows are relatively slow, the cultural landscape could be preserved through minimal maintenance (Pavlů et al. 2011) and decentralized use of Alpine resources in environmentally and socially responsible ways, in order to sustainably preserve rich cultural landscapes and alpine-specific forms of life and the economy (Bätzing 2015: 13).

\section{Conclusion}

This paper presented cultural landscape changes in an Alpine area. Because of the abandonment of traditional farming methods and the resultant afforestation, the traditional hay meadows and their associated hay barns are disappearing (see Schermer et al. 2016). A typical cultural landscape and the traditional construction methods which are an important part of Alpine cultural and technical heritage are also disappearing. The third conservation area of TNP is subject to building restrictions, and maintenance of the cultural landscape is supported. The future development of the area will largely depend, therefore, on the protected status of the cultural landscape and the protection regimes within TNP. We present a classification for the deterioration of hay barns and residential 


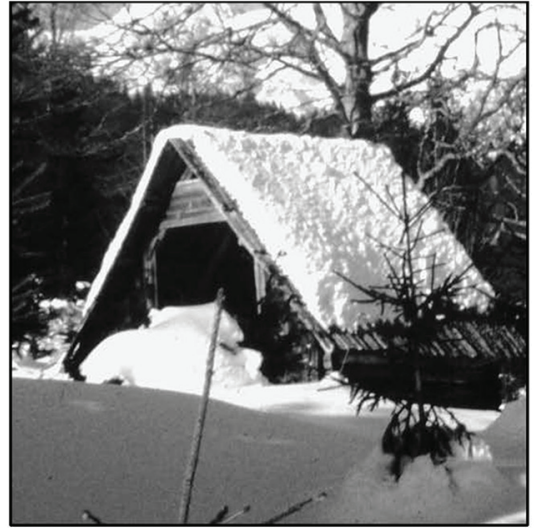

1985 (TYPE A)



2012 (TYPE B)

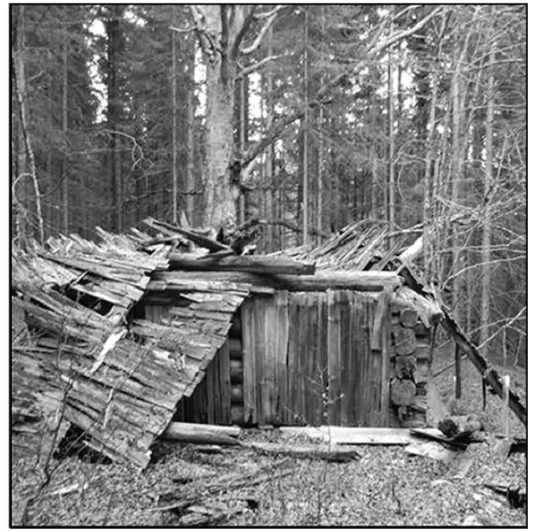

2015 (TYPE E)

Figure 8 - Deterioration of a particular hay barn (Nr. 02 in Figure 10) from 1985 (level A), to 2012 (level B), and 2015 (level E). (C) Kušar.

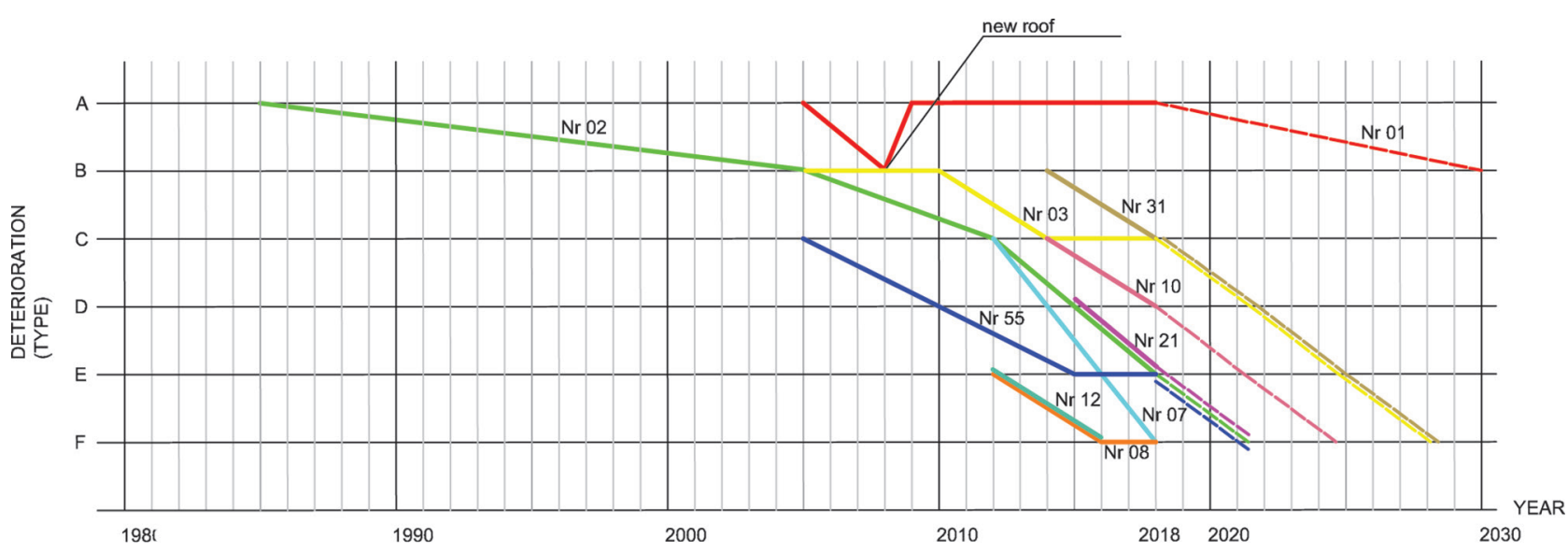

Figure 9 - Deterioration of ten sample bay barns over time (dashed lines show projections).

buildings, aiming to make this a proxy for the detection and projection of landscape changes. The use of traditional techniques in the renovation of buildings and of traditional construction methods for new developments in the area (see Bole et al. 2014) can also be used to determine the state of preservation of the cultural landscape more widely and can thus be applied to other areas.

\section{References}

Assandri, G., G. Bogliani, P. Pedrini \& M. Brambilla 2018. Beautiful agricultural landscape promote cultural ecosystem services and biodiversity conservation. Agriculture, Ecosystems \& Environment 256: 200-210.

Andrič, M., A. Martinčič, B. Štular, F. Petek \& T. Goslar 2010. Land-use changes in the Alps (Slovenia) in the fifteenth, nineteenth and twentieth centuries AD: a comparative study of the pollen records and historical data. The holocene 20(7): 1023-1037.

Antrop, M. 2005. Why landscapes of the past are important for the future? Landscape and Urban Planning 70(1-2): 21-34.
ARS [Archives of the Republic of Slovenia] 2016. Franciscejski kataster za Kranjsko, Bohinjska srednja vas 1823-1869. Ljubljana, Slovenia.

ARS [Archives of the Republic of Slovenia] 2016. SI AS 2067 - Korpus slovenske arhitekture [Corpus of the Slovenian Architecture]. Ljubljana, Slovenia. Available at: http://arsq.gov.si/Query/detail. aspx?ID=325293 (accessed: 20/06/2018)

ARSO [Agency of the Environment of the Republic of Slovenia]. 2015. Lidarski posnetek Slovenije. Available at: http://gis.arso.gov.si/evode/ profile.aspx?id=atlas_voda_Lidar@Arso (accessed: 15/02/2016)

Bätzing, W. 1988. Die Alpen. Entstehung und Gefährdung einer europäischen Kulturlandschaft. München. [In German]

Bätzing, W. 2015. Zwischen Wildnis und Freizeitpark. Zürich. [In German]

Bätzing, W. \& Y. Dickhörner 2001. The development of population in European Alpine region 18701990. A diachronic section study considering Alpine communities. Revue de Geographie Alpine 89(1): 11-20.

Bender, O., C.E. Roth \& H. Job 2017. Protected areas and population development in the Alps. eco.mont 9: 5-16. 
Bole, D., J. Nared \& M. Zorn 2016. Small urban centers in the Alps and their development issues. In: Zhelezov, G. (ed.), Sustainable Development in Mountain Regions.

Bole, D., M. Šmid Hribar, J. Kozina \& P. Pipan 2014. Sinergija kulture in turizma za razvoj podeželskih območij. Ljubljana. [In Slovenian]

Cevc, T. 1992. Bobinj in njegove planine - srě́anja s planšarsko kulturo. Didakta. Radovljica. [In Slovenian]

Cevc, T. 1995. Tipologija tradicionalnih pastirskih in planšarskih stavb v Slovenskih Alpah. Planšarske stavbe v Vzhodnih Alpah. Ljubljana. [In Slovenian]

Ciglič, R., M. Hrvatin, B. Komac \& D. Perko 2012. Karst as a criterion for defining areas less suitable for agriculture. Acta geographica Slovenica 52(1): 61-98.

Drole, E., S. Gaberšček, Z. Koželj, A. Kunstelj, M. Lah Sušnik, N. Leben, T. Lukan Klavžer, S. Roškar, M. Sagadin, A. Ščukovt, M. Vranješ \& I. Zakotnik 2012. Podatki o kulturni dediščini z oceno stanja. In: J. Kus Veenvliet (ed.), Iz̧odišča za Nắrt upravljanja Triglavskega narodnega parka 2012-2022. Javni zavod Triglavski narodni park. Bled. [In Slovenian]

Fister, P. 2002. Korpus slovenske arhitekture. AR arbitektura, raziskave 2: 132-133. [In Slovenian]

Fuchs, R., P.H. Verburg, J.G.P.W. Clevers \& M. Herold 2015. The potential of old maps and encyclopaedias for reconstructing historic European land cover/ use change. Applied Geography 59: 43-55.

Gabrovec, M. \& D. Kladnik 1997. Some new aspects of land use in Slovenia. Acta geographica 37: 7-64.

Gabrovec, M., B. Komac, J. Kozina, K. Polajnar Horvat, J. Nared, A. Smrekar, M. Topole \& M. Urbanc 2017. Triglav National Park, Slovenia, and its contribution to regional development. eco.mont 9: 57-65.

GIS [Geodetic Survey of Slovenia]. 2015. Scans of airborne geodetic photographs from 1956 and 1980 for the Uskovnica region. Ljubljana.

GURS [The Surveying and mapping authority of the republic of Slovenia]. 2015. Spletni portal Prostor. http://prostor3.gov.si/javni/javniVpogled. jsp? rand $=0.5047850835295608 \quad$ (accessed: 15/12/2015)

Herzog, T., J. Natterer, R. Schweitzer, M. Volz, \& W. Winter 2008. Timber Construction Manual. Basel, Berlin, Boston.

Hinojosa, L., C. Napoléone, M. Moulery \& E.F. Lambin 2016. The "mountain effect" in the abandonment of grasslands: Insights from the French Southern Alps. Agriculture, Ecosystems \& Environment 221: 115-124.

Höchtl, F., S. Lehringer \& W. Konold 2005. "Wilderness": what it means when it becomes a reality - a case study from the southwestern Alps. Landscape and Urban Planning 70(1-2): 85-95.

Hon, D.N.S. 1991. Photochemistry of wood. In: Wood and Cellulosic Chemistry: 525-555. New York.

Juvanec, B. \& D. Zupančič 2014. Besednjak vernakularne arbitekture. SAZU. Ljubljana. [In Slovenian]
Juvanec, B. 2009. Arbitektura Slovenije 1: Vernakularna arbitektura, alpski del.I2. Fakulteta za arhitekturo. Ljubljana. [In Slovenian]

Koderman, M. 2014. Razvoj počitniških bivališč v alpsko-jadranskem prostoru Slovenije 34:27-41. In: Vodeb, K.: Trajnostni razvoj turističnih destinacij AlpskoJadranskega prostora. Koper, Slovenia: Založba Univerze na Primorskem. [In Slovenian]

Komac, B. 2009. Social memory and geographical memory of natural disasters. Acta geographica Slovenica 49(1): 199-226.

Kušar, D. 2008. Kladna gradnja - slovenska tradicija. In: Kitek Kuzman, M., Gradnja z lesom. Ljubljana, Slovenia: Univerza v Ljubljani, Biotehniška fakulteta. [In Slovenian]

Kušar, D. \& J. Kušar 2018. Documentation and database on hay sheds in the Uskoonica pasture. Personal archive. Ljubljana.

Lasanta, T., J. Arnáez, N. Pascual, P. Ruiz-Flañob, M.P. Errea \& N. Lana-Renault 2016. Space-time process and drivers of land abandonment in Europe. Catena 149(3): 810-823.

MacDonald, D., J.R. Crabtree, G. Wiesinger, T. Dax, N. Stamou, P. Fleury, J. Gutiérrez-Lazpita \& A. Gibon 2000. Agricultural abandonment in mountain areas of Europe: environmental consequences and policy response. Journal of Environmental Management 59(1): 47-69.

Melik, A. 1950. Planine v Julijskih Alpah. Ljubljana, Slovenia: SAZU. [In Slovenian]

MKGP [Ministry of agriculture, forestry and food]. 2015. GERK - podatki o zemljiščih v uporabi kmetijskih gospodarstev. Available at: http://rkg.gov.si/ GERK/viewer.jsp (accessed: 15/06/2015)

Monteiro, A.T., F. Fava, E. Hiltbrunnerc, G. Della Marianna \& S. Bocchia 2011. Assessment of land cover changes and spatial drivers behind loss of permanent meadows in the lowlands of Italian Alps. Landscape and Urban Planning 100(3): 287-294.

Nared, J., N. Razpotnik Visković \& B. Komac 2015. Sustainable spatial development in the Alps. Acta geographica Slovenica 55(1): 161-163.

NORDREGIO 2004. Mountain areas in Europe: analysis of mountain areas in EU member states, acceding and other European countries. Commissioned report by the European Commission - DG Regional Policy. Brussels. Available at: http://ec.europa.eu/ regional_policy/sources/docgener/studies/pdf/ montagne/mount1.pdf (accessed: 15/06/2015)

Ogrin, D. 1996: Podnebni tipi v Sloveniji. Geografski vestnik 68: 39-65. [In Slovenian]

Pavlů, L., V. Pavlů, J. Gaislera, M. Hejcman \& J. Mikulka 2011. Effect of long-term cutting versus abandonment on the vegetation of a mountain hay meadow (Polygono-Trisetion) in Central Europe. Flora - Morphology, Distribution, Functional Ecology of Plants 206(12): 1020-1029. 
Perko, D., M. Hrvatin \& R. Ciglič 2017. Determination of landscape hotspots of Slovenia. Acta geographica Slovenica 57(1): 7-29.

Plieninger, T., F. Höchtl \& T. Spek 2006. European Rural Landscapes: Land-use, biodiversity, and conservation. Environmental Science \& Policy 9(4): 317-321.

Pohleven, F. 1998. Zaščita lesa pred škodljivci. Gradbenik. 2(12): 10-13. [In Slovenian]

Pučnik, J. 1965. O dilemah našega kmetijstva. Perspek.tive 33-34. Ljubljana. [In Slovenian]

Schermer, M., I. Darnhofer, K. Daugstad, M. Gabillet, S. Lavorel \& M. Steinbacher 2016: Institutional impacts on the resilience of mountain grasslands: an analysis based on three European case studies. Land Use Policy 52: 382-391.

Scotton, M., L. Sicher \& A. Kasal 2014. Semi-natural grasslands of the Non Valley (Eastern Italian Alps): agronomic and environmental value of traditional and new Alpine hay-meadow types. Agriculture, Ecosystems \& Environment 197(1): 243-254.

Smrekar, A. 2016: The beauty of landforms. Acta geographica Slovenica 56(2): 321-335.

Tasser, E., J. Walde,U. Tappeiner, A. Teutsch \& W. Noggler 2007. Land-use changes and natural reforestation in the Eastern Central Alps. Agriculture, Ecosystems \& Environment 118(1-4): 115-129.

Terres, J.M., L.N. Scacchiafichi, A. Wania, M. Ambar, E. Anguiano, A. Buckwell, A. Coppola, A., Gocht, H. Nordström Källström, P. Pointereau, D. Strijker, L. Visek, L. Vranken \& A. Zobena 2015: Farmland abandonment in Europe: Identification of drivers and indicators, and development of a composite indicator of risk. Land Use Policy 49: 20-34.

Torelli, N. \& K. Čufar 1983. Sorpcija in stabilnost lesa. Les 35(5-6): 101-106. [In Slovenian]

United States Department of Agriculture, Forest Service 1986. Wood decay in houses - How to prevent and control it. Home and Garden Bulletin 73. Available at: https://naldc.nal.usda.gov/download/12758/ PDF (accessed 27/06/2018)
Wang, L. 2015. Old barn hides a contemporary larch-lined holiday home in the Swiss Alps. Available at: http://inhabitat.com/old-barn-hides-acontemporary-larch-lined-holiday-home-in-the-swissalps / (accessed 01/09/2017)

VSRS [Supreme Court of the Republic of Slovenia]. Zemljiška knjiga. Ljubljana. Available at: https:/ / evlozisce.sodisce.si/esodstvo/index.html (accessed 14/12/ 2015)

Zakon o Triglavskem narodnem parku [Law on the Triglav National Park]. Uradni list (S)RS 17/1981, 18/1981, 42/1986,8/1990, 35/2001, 110/2002 in 52/2010. Ljubljana, Slovenia.

Zupan, G., M. Ferenc \& F.M. Dolinar 1993. Cerkve na Kǒ̌evskem nekoč in danes (Die Gottscheer Kirchen einst und heute). Založba ZRC. Ljubljana. IIn Slovenian]

\section{Authors}

\section{Domen Kušar (corresponding author)}

is an assistant professor at the Faculty of Architecture at the University of Ljubljana. He has a $\mathrm{PhD}$ in Architecture (University of Ljubljana). His main research areas are architecture, prefabrication, geometry, wooden construction and safety. University of Ljubljana, Faculty of Architecture. Zoisova ulica 12, 1000 Ljubljana, Slovenia E-mail: domen.kusar@fa.uni-lj.si

\section{Blaž Komac}

is a senior research fellow at the Research Centre of the Slovenian Academy of Sciences and Arts, Anton Melik Geographical Institute (Ljubljana). He holds a $\mathrm{PhD}$ in Geography (University of Ljubljana). His main research areas are geomorphology, natural hazards, and geographic information systems. Research centre of the Slovenian Academy of Science and Arts, Anton Melik Geographical Institute. E-mail: blaz@ zrc-sazu.si 